\title{
Exploring teachers professional identity: Role of teacher emotions in developing professional identity
}

\section{Manpreet Kaur}

Associate Professor, Partap College of Education, Ludhiana, Punjab, India

\begin{abstract}
The purpose of this study is to develop an understanding of the connections between teacher's emotional development and professional identity. Twenty teachers in their beginning year of profession were interviewed to reflect on emotional events and how these emotions help them in developing their professional identity. The research question for this study is; how do teachers' reflections of emotional events contribute in the development of their professional identity? Findings of the research yielded a model of professional identity that reflected the teachers understanding of themselves in relation to different emotional events. This model includes four key indicators: a) Identity beliefs, b) emotional events and identity negotiation, c) Teachers' attributes and d) adjustment. All participants exhibited the role of emotional events in development of professional identity. Some teachers elaborated that pleasant emotional events confurmed their identities and others elaborated the unpleasant emotional events which caused them to confront and adjust their emergent identities.
\end{abstract}

KEY WORDS: PROFESSIONAL IDENTITY, TEACHER EMOTIONS

\section{INTRODUCTION}

Teachers' professional identity has emerged as a separate area of research (Bullough, 1997; Claudia et al , 2013; Connelyly and Clandinin, 1999; Kompf, Bond, Dworet \&t Boak, 1996). The concept of identity is defined in various ways in research literature and the concept of professional identity is used in different ways in the domain of teaching and teacher education. In some studies, the concept of professional identity was related to teachers' concepts or images of self (i.e., Claudia et al, 2013; Nias, 1989) and it was argued that these concepts or images of self strongly determine the way teachers teach, the way they develop as teachers, and their attitudes towards educational changes. Professional identity formation is a method involving many knowledge sources, such

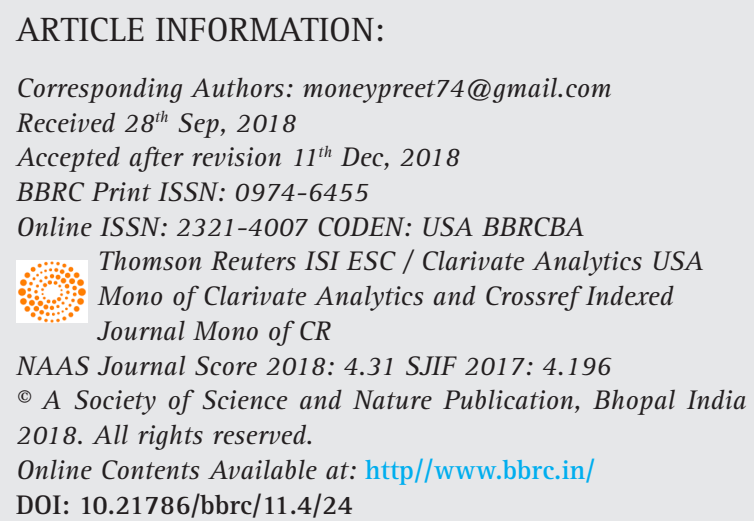


as knowledge of affect, teaching human relations and subject matter (Antonek et al., 1997). Professional identity formation is often presented as a struggle because teachers have to make sense of varying and sometimes competing perspectives, expectations and roles that they have to confront and adapt to (Samuel \&t Stephens, 2000; Volkmann \&t Anderson, 1998; see also Bullough, Knowles \&t Crow, 1992; Mawhinney \&t Xu, 1997; Roberts, 2000). Research proved the crucial role of teaching practice and reflective activities in the identity formation of teachers (Ilze \&t Rita, 2016). Researching professional identity at early career stages can help educators to emphasize the multidimensionality and complexity of the teaching profession (Predrag, Biljana \&t Dusan, 2018)

Professional identity is an ongoing process of interpretations and reinterpretation of experiences (Kerby, 1991), a notion that corresponds with the idea that teacher development never stops and can be best seen as a process of lifelong learning (i.e., Day, 1999; Graham \&t Young, 1998). From a professional development perspective, therefore, professional identity formation is, in our view, not only an answer to the question "Who am I at this moment?", but also an answer to the question "Who do I want to become?" Professional Identity implies both person and context. A teacher's professional identity is not entirely unique. Teachers are expected to think and behave professionally, but not simply by adopting professional characteristics, including knowledge and attitudes that are prescribed but also by including personal characteristics. Chang-Kredl \&t Kingsley (2014) also emphasise the dynamic nature of professional identity; it is a continuous process in which identity is formed, built, and shaped. Teachers differ in the way they deal with these characteristics depending on the value they personally attach to them.

Generally, it is stated that professional identity is dynamic (e.g. Beijaard et al. 2004). Sugrue (2005) elaborates on this and argues that identity is not distinctly individual and unalterable. People may strive to maintain their habits and routines, but are not immune to outside influences (Sugrue, 2005). Teachers obtain more and more experience, and more and different influences affect teachers as teachers have worked longer in their profession. Ibarra (1999) poses that people use trial versions of their professional identity before assuming a fully elaborated professional identity.A teacher's professional identity consists of sub-identities that more or less harmonize. The notion of sub-identities relates to teachers' different contexts and relationships. Some of these identities may be broadly linked and can be seen as the core of teachers' professional identity, while others may be more peripheral. It seems to be essential for a teacher that these sub-identities do not conflict, for example, that they are well balanced. During initial teacher training student teachers often experience such conflict (i.e. Volkmann \& Anderson, 1998).

\section{TEACHER EMOTIONS}

Teacher emotions have been regarded as an important field of research over the past two decades (Frenzel etal., 2009; Fried et al., 2015). Teacher professional development research has been continuously focused towards investigating the so-called 'rational' factors (e.g., teacher knowledge, skills, and capacities). However important these rational and fundamental aspects are, teacher emotions have often been ignored or underplayed (Crawford, 2011; Day, 2011; Hargreaves, 2001; Sutton \&t Wheatley, 2003) in teacher improvement and identity formation initiatives.Emotion is a mysterious human phenomenon that has puzzled many for centuries. Schutz, Hong, Cross, and Osbon (2006) define emotions as "socially constructed, personally enacted ways of being that emerge from conscious and/or unconscious judgments regarding perceived successes at attaining goals or maintaining standards or beliefs during transactions as part of social-historical contexts".

Research on teacher emotions in education has warranted attention since the late 1990s (Hargreaves, 1998; Marshak, 1996) and has attracted increased attention in recent years. This is motivated by the realization that teacher emotions influence teacher behaviour (Becker, Goetz, Morger, \& Ranellucci, 2014; Hagenauer \& Volet, 2014; Sutton \&t Wheatley, 2003), teaching (Gong, Chai, Duan, Zhong, \&t Jiao, 2013; Saunders, 2013; Trigweel, 2012), professional identity (Lee, Huang, Law, \&t Wang, 2013), teachers' lives (Hargreaves, 2005; Schutz, 2014; Schutz \& Zembylas, 2009; Taxer \&t Frenzel, 2015), student behaviour and learning (Brackett, Floman, AshtonJames, Cherkasskiy, \&t Salovey, 2013; Chang, 2013; Jennings \& Greenberg, 2009), and educational change (Day, 2011; Leithwood \& Beatty, 2007). Although previous research on teacher emotions has made substantial progress, it has most frequently used semi-structured interviews (Sutton \&t Wheatley, 2003).

Farouk (2012) states that teacher emotions comprise individual teacher's dynamic mental state level, ability of emotional self-regulation and response to exterior stimuli, and an approach of synthesis. Teacher emotions are not "internalized sensations that remain inert within the confines of their bodies but are integral to the ways in which they relate to and interact with their students, colleagues and parents" (Farouk, 2012). Therefore, teacher emotions are relational with the environment, which means teacher emotions do not exist within an individual or environment independently, rather they involve person-environment transactions (Schutz et al., 2006). Understanding emotions triggered by vulnerabil- 
ity may constitute an opportunity for teachers to educate in a way that really makes a difference to students' and teachers' lives but also teacher effectiveness (Day et al., 2007; Kelchtermans, 2005, 2011). Emotions have great potential to strengthen not only interpersonal relationships experienced in the classroom and broader contexts, but also create opportunities for learning and teaching in various situations (Bahia et al., 2013). A lack of negative emotions also limited teachers' learning processes (Klara et al; 2017).

\section{TEACHER IDENTITIES AND TEACHER EMOTIONS}

Although there is a great variation in how scholars define and measure teacher identities (e.g. Beijaard, Meijer, \&t Verloop, 2004), growing literature suggests three salient features. First, identities are not fixed, but fluid processes involving 'interpretation and reinterpretation of experience' (Sutherland, Howard, \& Markauskaite, 2010) i.e. it is not about what someone is, but rather identity is about what someone is becoming. Second, it involves a negotiation between the person and an understanding of the contexts in which he/she works. And third, it involves human agency.

Yoo and Carter (2017) carried out an ethnographic study in the form of a professional development program focused on creative writing and writing practices. They identified four different types of emotions that the participants experienced: (1) energy, excitement, and passion; (2) inner conflict, frustration, and discouragement; (3) vulnerability, engagement, and hope; and (4) generosity, gratitude, and inspiration. This line of research shows that every change, reform, or development in teaching is accompanied by various emotions. Related to that emerging teacher identity, Nias (1996) indicated that teaching is not just a technical job; rather, teachers invest their 'selves' into their work. This investment involves emotional experiences that provide salient information regarding one's evolving identity commitments. Importantly, this relationship is reciprocal and teachers' emerging identities not only influence their actions and emotions, but their actions and emotions also influence their professional identity formation. Teacher identity and emotion are not linear or unidirectional; rather, they are inextricably related to each other through an ongoing, multidirectional, transactional process. For example, when teachers experience particular unpleasant emotions, those emotions may indicate or signal a threat to their identities by challenging existing identities related to their beliefs about teaching. In contrast, pleasant emotional episodes may indicate a confirmation of an emerging identity (Cross \& Hong, 2009). Similarly, incoming identities (e.g. expectations about a teacher's role) may influence how subsequent emotional reactions emerge and/or are interpreted.

\section{RESEARCH AIMS}

Previous research provides a little knowledge about the importance of emotions in teaching and the emerging identities of beginning career teachers; this research is an attempt to understand how these two connect. Therefore, the goal of this inquiry was to ask beginning teachers to reflect on pleasant and unpleasant emotional episodes early in their first year in the classroom and to discuss the ways in which these emotional experiences help them in development of professional identities. The purpose of the research is to draw on teachers' reflections about emotional events and identity constructs to begin to theorize on their connections. Through openended semi-structured interviews, teachers were asked to reflect on emotional events as a way to begin to understand the ways emotions may contribute in emergent identity processes. These emotional events are seen as 'beacons of our true selves' and 'become the fulcrums through which we begin to deconstruct and construct our sense of self' (Zembylas, 2003).

\section{METHODS}

This paper encompassed a pilot qualitative study to respond to the research question that how teachers in their beginning years develop an understanding of emotional events in their classroom and how these emotional events relate to their emerging teacher identities.

\section{PARTICIPANTS}

Participants of the study were twenty teachers in their beginning year of profession teaching in eight different high schools across the state of Punjab of India. They ranged in age from 25 to 31 (average 28), included six males and fourteen females. Our participants taught science $(n=12)$ and math $(n=8)$ in schools. Objective of the study was to listen to how beginning year teachers who confront emotional events more frequently than more experienced teachers, talk about the ways in which those events update their beliefs about teaching and their identities as an emergent teaching professional. Data was collected from interviews of teachers in their first school year. All interviews were lasted between 60 and $90 \mathrm{~min}$. In this interview, teachers were asked to reflect upon pleasant and unpleasant emotional episodes they had experienced. For example, 'Describe a recent occasion when you were aware of your emotions in the classroom, and 'how do you think your emotional experiences affect how you think about yourself as a teacher?' This interview structure was designed to allow the participants to reflect on past experiences with emotions in the classroom and to discuss their thoughts 
regarding how they feel themselves as teachers and the role emotional events may have played in this.

\section{DATA ANALYSIS}

Participants' responses to each question in the interviews were compiled and themes were examined from two perspectives: within and across participants. The semi-structured format of interview helps to compare the responses of participants. Each participant was asked to discuss his/her pleasant and unpleasant emotional events in the classroom and their reactions to these events. Themes emerged when considering responses across each participant. In the second step data was compared to the relevant literature on professional identities and emotional labor. Multiple readings of the transcripts ensured that our emergent themes reflected the overall context (Groenewald, 2004; LeCompte \& Preissle, 1993; Thompson, Locander, \&t Pollio, 1989). Collectively, these processes fulfilled our goal to capture participants' most salient experiences related to understanding how emotional events signal and influence their emerging teacher identities.

\section{RESULTS}

Findings of the research yielded a model of professional identity that reflected the teachers understanding and development of themselves in relation to different emotional events. This model includes four key indicators: 1) Identity beliefs, 2) Emotional events and identity negotiation 3) Teachers' attributes and 4) Adjustment

\section{1) Identity beliefs}

Identity beliefs represent reference points teachers used to determine where they are as compared to where they want to be. Within the interviews with participants, a variety of statements were identified that reflected some divergent expectation. For example, Mr Sunil Kumar (a 28-year-old science teacher) exclaimed that: 'I never realized that how difficult it is to be a teacher, suggesting that what he was experiencing was basically not what he expected, suggesting he is experiencing emotional problem. Ms Rashmi (a 30-year-oldmaths teacher), stated that: 'I know math but, what is coming out is not matching with what I need to do for them.'

By contrast, a few of teachers expressed incoming identity beliefs that were often not too far from what they experienced or how they expected to be in the classroom. For example, Ms Shweta (a 27-year-old science teacher), seemed very clear in asserting that she was not a 'traditional' teacher but saw herself as 'very open minded and enthusiastic.' Her openness led her to observe that her students think of her as 'their mom' because she's 'so caring.' In this case, her expectations played out in ways that may not lead to identity struggles in the classroom. Ms Meena (a 30-year-old Math teacher) also seemed to know more clearly who she was as a teacher. Ms Meena saw herself as someone who is kind, not a dictator, and someone who tries to "take their (students) feelings into consideration.'

These examples illustrate how participants' incoming identity beliefs were sometimes challenged as they continued the process of becoming a teacher. Among most of the participants, there was a clear struggle present as they searched for ways to reconcile incoming beliefs and expectations with the living experiences of teaching. These matches and mismatches resulted in emotional events that associate with teachers' identity and the emotional efforts associated with that identity belief.

\section{2) Emotional Events and Identity Negotiation}

An emotional event refers to those emotions that are triggered by some social interaction or experience with students, teachers, or administration. Although not all emotional events have the potential to influence a teacher's emerging identities, there are examples where the critical emotional event seemed directly tied to some ongoing identity negotiation. Participants' experiences suggested that these emotional events could be either pleasant or unpleasant. For example, Ms Kiran (a 26-year-old beginning science teacher) talked about the 'stress' she experienced as she attempted to get 'all' of her students to 'love science.' For Ms Kiran, it was an overwhelming feeling to handle her 'challenging' class.

By contrast, there were also a number of pleasant emotional events that seemed to affirm some of these beginning teachers' identities about themselves as teachers. For example, students of Ms Rashmi's other classes were 'really engaged' and 'interested.' Mr Rajneesh (a 28- year- old math teacher) talked about the 'joy of just seeing the excitement in the students.' Mr Shubham (a 31-year-oldscience teacher), talked about the joy he experienced 'when the class is really attentive and enthusiastic, it feels really good.'

In general, these emotional events either tended to call into question or affirmed participants' perceptions of themselves as teachers.

\section{3) Teachers' attributes}

Participants of the study varied in the attributes and argued that pleasant and unpleasant emotional events influenced their attributes like job satisfaction, flexibility, understanding, awareness, encouragement, motivation That is, teachers at times reported that emotionally challenging/satisfying events were either due to reasons under their personal control (they are a bad/good teacher), or not under their control (I have no power 
over these students).External control seemed more prevalent when it came to unpleasant emotional events. For example, Mr Sunil accepts that he could not motivate his students was because science was not 'relevant' to them. Likewise, Ms Kiran indicated that her students 'don't care' and Ms Meena talked about struggles she was having while she attempted to teach students who are 'not motivated'. In these examples, teachers make sense of frustrating emotional events in terms of factors that are perceived to be beyond their personal control (i.e. the problems rest within the students, not within them) and influence their attributes.

However, there were also examples of internal control. For example, Mr Suraj talked about feeling helpless because 'you don't really know what to do to fix something.' He also talked about 'doing a bad job, suggesting that at the end of the day, when he is feeling frustrated, he feels like he is 'doing a bad job. Ms Manjeet (29-yearold science teacher) talked at length about her relative 'inexperience' in dealing with students who were very close to her and who persistently challenged her ability to understand students nature and attitude and what it means to be a teacher. For example, Ms Manjeet believed that a teacher should be 'understanding and flexible.' However, by enacting these dispositions with her students, it invited experiences that challenged these beliefs leading her to question whether or not she should be 'harder' or stricter with students. She attributed failure to handle students due to lack of experience. These teachers were actively trying to better understand themselves, their control, and their role in teaching their students.

Some participants approached emotional events related to classroom management in a more useful manner. Ms Sharda (25 year-old math teacher) said, 'I feel I am doing something good, even if it is bad, I can learn from it.' Similarly, Mr Shubham offers a more balanced attribution analysis of his role in students' lives. When students didn't do well, he experienced frustration and often wondered what he could have done differently to get them to remember what he is teaching. But he also expressed his awareness that the responsibility lies with both him and his students - it is a shared effort and therefore shared responsibilities. But he still seems to be working through this idea that if students are struggling, he understands and is patient as teacher that they are trying and therefore, he must try not to be overly frustrated with them - or at least shouldn't let them know he is frustrated.

\section{4) Adjustment}

Some of participants also talked about how emotional episodes were often times presented as valuable opportunities to learn what kind of adjustments they needed to make to the way they were approaching situations and thinking about teaching. Many of these experiences cantered on classroom management.

Ms Seema (a 26-year-old math teacher) was a particularly interesting case as a new teacher who was dipped in questions about how to adjust his teaching efforts and identity. This was revealed when she shared how she felt about being a teacher and feeling emotionally invested in her students. During her interview, Ms Seema broke out in tears and said, I love them, they are like my kids. I never thought it would be something that I am experiencing at all. I mean...when they start telling me their problems (crying) I wish I could do more for them and I want to be sympathetic but I can't be, Ms Seema revealed an emergent emotional struggle that forces her to reflect on her identity as a teacher. Her interactions with these students prompted a deep sense of empathy for their problems and a desire to 'save' them, but at the same time, caused her to struggle because it conflicted with what it meant to be a teacher to these students. For Ms Seema, emotional events with her students signalled a deep conflict between her 'fantasy' teacher identity (I can teach them all and save them all) and her 'survival' teacher identity (I just have to find a way to cope) (Bullough, 2009).

For Ms Kiran, it was about figuring out how to handle ongoing frustration with students who she felt were chronically not engaged. Initially she felt so 'overwhelmed' and 'frustrated 'that maybe she wasn't 'cut out for teaching' But over the time, she made adjustments that were learned through ongoing experiences with her students who she saw as not always so unengaged. For Ms Kiran, her ideas of teaching and specifically her beliefs about her capacity to be a good teacher were shaped over time by positive and negative experiences in engaging students in science.

\section{DISCUSSION AND IMPLICATIONS}

Participants could identify emotional events that were signals for 'teacher identity' -the active process of constructing and deconstructing understanding of what it means to be a teacher as one reflectively confronts the process and outcome of some emotionally engaging classroom-based events. Frustration originating from a perceived lack of control, or experiences that conflicted with incoming expectations often led to some type of identity work (i.e. teachers wondered what kinds of shifts they needed to make to cope or make things different in their classroom), as we see in the cases of teachers such as Mrs Kiran and Ms Seema, respectively. Satisfaction coming from successful teaching events often confirmed teaching identities. For most of our participants, feelings of happiness, joy, or satisfaction often accompanied successful teaching events and days defined as events in 
which students were engaged or demonstrably learned something. For these moments, the positive emotions emanating from how students behaved often confirmed what it means to be a 'successful' teacher - sometimes independent of whether they had control over the situation or not. Teacher attributes and adjustments were also identifiable in the identity processes. Reflections on emotional events often led to sense making exercises in the form of attributes and potential adjustments.

Although these reflections seem to coincide with directional hypothesis of this study about the process of 'identity formation' for new teachers (i.e. beliefs, emotions, attributes, adjustment), not all teachers' reflections lined up this way, suggesting that the connections between these four features are multi-layered and multidirectional. It may well be the case that evolving emotions play a larger role in triggering later identity processes. It is also true that teachers' identity development includes a much wider swath of experiences than just what happens in the classroom. Although relationships with students and relevant instructional experiences play a significant role in a teacher's life, this narrow view neglects the broader contexts of teaching that include relationships with colleagues, administrators, and the press to fulfil many externally imposed demands and policies. These may be the limitations of this study.

This research will add to existing literature examining how teachers come to understand what it means to be a teacher. From this study, one can learn the importance of emotional events in shaping the nature of teachers' identities. As an example, this study suggests that emotional experiences that conflict with new teachers' expectations of what it means to be a teacher have great potential to trigger 'identity formation.' In fact, it seems as if these gaps between expectations and experiences have great potential for triggering important opportunities for teachers to engage in active explorations about what it means to be a teacher. This study yielded a model of 'identity work' that involves (1) some beginning orientation of teacher identity beliefs, (2) the experience of pleasant/unpleasant emotional events, and (3) teacher attributes and (4) identity adjustment (or change in beliefs about self as teacher). This model provides an entry point for scholars to understand on how emotions and identity processes converge and emerge. As a starting point, the model helps generate lines of future inquiry. For example, are emotional events the only source of identity adjustments? What is the significance of pleasant vs. Unpleasant emotional events for influencing identity-based attributes and adjustments?

This study has the potential to provide avenues for enhancing teacher education programs, particularly the pre service teacher experience when teachers are beginning to get their 'feet wet' in actual classroom settings. It is only through direct teaching experiences that teachers can be made aware of the range of emotional struggles they will encounter in their future classrooms. In this regard, teacher education programs should provide training in mindfulness exercises including emotional responses to students and events. Teachers should regularly record the range of emotional experience they observe and undergo as student teachers. This could assist these trainees with how to think and act through the many conflicting situations and emotional events of teaching.

\section{REFERENCES}

Antonek, J. L., McCormick, D. E., \&t Donato, R. (1997). The student teacher portfolio as autobiography: Developing a professional identity. Modern Language Journal, 81(1), 15-27.

Bahia, S., Freire, I., Amaral, A., \&t Estrela, M. T. (2013). The emotional dimension of teaching in a group of Portuguese teachers. Teachers and Teaching: Theory and practice, 19, 275-292.

Becker, E. S., Goetz, T., Morger, V., \&t Ranellucci, J. (2014). The importance of teachers' emotions and instructional behavior for their students' emotions-An experience sampling analysis. Teaching and Teacher Education, 43, 15-26.

Beijaard, D., Meijer, P. C., \&t Verloop, N. (2004). Reconsidering research on teachers' professional identity. Teaching and Teacher Education, 20, 107-128.

Brackett, M. A., Floman, J. L., Ashton-James, C., Cherkasskiy, L., EtSalovey, P. (2013). The influence of teacher emotion on grading practices: A preliminary look at the evaluation of student writing. Teachers and Teaching: Theory and Practice, 19(6), 634-646. http://dx.doi.org/10.1080/13540602.2013.827 453.

Bullough, R.V. (1997). Practicing theory and theorizing practice. In J. Loughran\&t T. Russell (Eds.) Purpose, passion and pedagogy in teacher education pp.13-31). London : The Falmer Press.

Bullough, R.V.,Knowles,G., \&t Crow, N.A. (1992). Emerging as a teacher. London: Routledge.

Chang-Kredl, S., \&t Kingsley, S. (2014). Identity Expectations in Early Childhood Teacher Education: Pre-service Teachers' Memories of Prior Experiences and Reasons for Entry into the Profession. Teaching and Teacher Education, 43, 27-36.

Chang, M. L. (2013). Toward a theoretical model to understand teacher emotions and teacher burnout in the context of student misbehavior: Appraisal, regulation and coping. Motivation and Emotion, 37, 799e817. http://dx.doi.org/ 10.1007/s11031012-9335-0.

Claudia, L. R., Anca, R.T. , Oana L. R., \&t Livia, A. (2013). Teachers' Professional Identity: A Content Analysis. Procedia Social and Behavioral Sciences 78, 315 - 319.

Connelly, F.M., \&t Clandinin, D.J. (1999). Shaping a professional identity: Stories of education practice. London, Ontario :Althouse Press. 
Crawford, M. (2011). Rationality and emotions. In C. Day, \& L. Chi-kin (Eds.), New understandings of teacher education: Emotions and educational change. LaVergne, TN: Springer.

Cross, D. I., \& Hong, J. Y. (2009). Beliefs and professional identity: Critical constructs in examining the impact of reform on the emotional experiences of teachers. In P. A. Schutz\&t M. Zembylas (Eds.), Advances in teacher emotion research: The impact on teachers' lives (pp. 273-296). New York, NY: Springer.

Day, C. (2011). New understandings of teachers work: Emotions and educational change. New York: Springer.

Day, C. (1999). Developing teachers, the challenge of lifelong learning. London: The Falmer Press.

Day, C., Sammons, P., Stobart, G., \&t Kington, A. (2007). Variations in the work and lives of teachers: Relative and relationship effectiveness. Teachers and Teaching: Theory and Practice, 12(2), 169e192.

Farouk, S. (2012). What can the self-conscious emotion of guilt tell us about primary school teachers' moral purpose and the relationships they have with their pupils? Teachers and Teaching: Theory and Practice, 18(4), 491-507.

Frenzel, A. C., Goetz, T., Stephens, E. J., \&t Jacob, B. (2009). Antecedents and effects of teachers' emotional experiences: An integrated perspective and empirical test. In P. A. Schutz \& M. Zembylas (Eds.), Advances in teacher emotion research: The impact on teachers' lives (pp. 129-151). New York: Springer.

Fried, L., Mansfield, C., \&t Dobozy, E. (2015). Teacher emotion research: Introducing a conceptual model to guide future research. Issues in Educational Research, 25(4), 415-441.

Gong, S., Chai, X., Duan, T., Zhong, L., \&t Jiao, Y. (2013). Chinese teachers' emotion regulation goals and strategies. Psychology, 4 (11), 870e877. 10.4236/psych.2013.411125. http:// dx.doi.org/

Graham, R., \&t Young, J. (1998), Curriculum, identity and experience in multicultural education. The Alberta Journal of educational Research, 44(4), 397-407.

Groenewald, T. (2004). A phenomenological research design illustrated. Article 4. International Journal of Qualitative Methods, 3, 42-55.

Hagenauer, G., \&tVolet, S. E. (2014). “I don’t hide my feelings, even though I try to": Insight into teacher educator emotion display. Australian Educational Researcher, 41, 261e281. http:// dx.doi.org/10.1007/s13384-013-0129-5

Hargreaves, A. (1998). The emotional politics of teaching and teacher development: With implications for educational leadership. International Journal of Leadership Education, 1, 315336.

Hargreaves, A. (2001). Emotional geographies of teaching. Teachers College Record, 103(6), 1056-1080.

Ibarra, H. (1999). Provisional selves: Experimenting with image and identity in professional adaptation. Administrative Science Quarterly, 44, 764-791.

Ilze, I., \&t Rita S. (2016). Development of Professional Identity during Teacher's Practice. Procedia - Social and Behavioral Sciences 232, $529-536$.
Jennings, P. A., \&t Greenberg, M. T. (2009). The prosocial classroom: Teacher social and emotional competence in relation to student and classroom outcomes. Review of Educational Research, 79 (1), 491-525. http://dx.doi.org/10.3102/ 0034654308325693.

Kelchtermans, G. (2005). Teachers' emotions in educational reforms: Self understanding, vulnerable commitment and micro political literacy. Teaching and Teacher Education, 21, 995-1006.

Kelchtermans, G. (2011). Vulnerability in teaching: The moral and political roots of structural conditions. In C. Day, \& J. C. K. Lee (Eds.), New understanding of Teacher's Work: Emotions and educational change (pp. 65e84). New York: Springer

Kerby, A.(1991). Narrative and the self. Bloomington, IN: Indiana University Press.

Klara, S., Zuzana, S., Roman, S.,\&t Martin, S. (2017). Teachers' emotions in teacher development: do they matter? Studia paedagogica. 22(4). doi.org/10.5817/SP2017-4-5

Kompf, M. Bond, W.R., Dworet, D., \&t Boak, R.T. (Eds.). (1996) Changing research and practice: Teachers' professionalism, identities and knowledge. London: The Falmer Press.

Le Compte, M. D., \& Preissle, J. (1993). Analysis and interpretation of qualitative data. Ethnography and qualitative design in educational research. New York, NY: Academic Press.

Lee, J. C. K., Huang, Y. X. H., Law, E. H. F., \&Wang, M. H. (2013). Professional identities and emotions of teachers in the context of curriculum reform: A Chinese perspective. AsiaPacific Journal of Teacher Education, 41(3), 271-287.

Leithwood, K. A., \&t Beatty, B. (2007). Leading with teacher emotion in mind. Thousand Oaks, CA: Corwin Press.

Marshak, D. (1996). The emotional experience of school change: Resistance, loss, and grief. NASSP Bulletin, 80 (577), 72-77.

Mawhinney, H., \&t Xu, F. (1997). Restructuring the identity of foreign -trained teachers in Ontari schools. TESOL Quarterly, 31(3), 632-639.

Nias, J. (1996). Thinking about feeling: The emotions in teaching. Cambridge Journal of Education, 26, 293-306.

Nias, J. (1989). Teaching and the self. In M.L. Holly \&t C.S. McLoughlin (Eds.), Perspective on teacher professional development (pp.151-171). London: The Falmer Press.

Predrag, Z., Biljana, S., \&t Dusan, R. (2018). Student Teachers' Professional Identity: Research in the Republic of Serbia. The New Educational Review. DOI: 10.15804/tner.2018.51.1.18

Roberts, L. (2000). Shifting identities: An investigation into student and novice teachers' evolving professional identity. Journal for Teaching, 26 (2), 185-186.

Samuel, M., \&tStephens, D. (2000). Critical dialogues with self: Developing teacher identities and roles - A case study of South Africa. International Journal of Educational Research, 33(5), 475-491.

Saunders, R. (2013). The role of teacher emotions in change: Experiences, patterns and implications for professional devel- 
opment. Journal of Educational Change, 14, 303-333. http:// dx.doi.org/10.1007/s10833-012-9195-0.

Schutz, P. A. (2014). Inquiry on teachers' emotion. Educational Psychologist, 49 (1), 1-12. http://dx.doi.org/10.1080/0046152 0.2013 .864955 .

Schutz, P. A., \&t Zembylas, M. (2009). Advances in teacher emotion research: The impact on teachers' lives. Dordrecht, the Netherlands: Springer.

Schutz, P. A., Hong, J. Y., Cross, D. I., \&t Osbon, J. N. (2006). Reflections on investigatingemotion in educational activity settings. Educational Psychology Review, 18 (4), 343-360.

Schutz, P. A., Hong, J. Y., Cross, D. I., \&t Osbon, J. N. (2006). Reflections on investigating emotion in educational activity settings. Educational Psychology Review, 18 (4), 343-360.

Sugrue, C. (2005). Revisiting teaching archetypes. In D. Bijaard, P. C. Meijer, G. Morine-Dershimer, \&t H. Tillema (Eds.), Teacher professional development in changing conditions. Dordrecht: Springer.

Sutton, R. E., \&t Wheatley, K. F. (2003). Teachers' emotions and teaching: A review of the literature and directions for future research. Educational Psychology Review, 15, 327-358.
Taxer, J. L., \&t Frenzel, A. C. (2015). Facets of teachers' emotional lives: A quantitative investigation of teachers' genuine, faked, and hidden emotions. Teaching and Teacher Education, 49, 78-88.

Thompson, C. J., Locander, W. B., \&t Pollio, H. R. (1989). Putting consumer experience back into consumer research: The philosophy and method of existential-phenomenology. Journal of Consumer Research, 16, 133-146.

Trigweel, K. (2012). Relations between teachers' emotions in teaching and their approaches to teaching in higher education. Instructional Science, 40, 607e621. http://dx.doi.org/10.1007/ s11251-011-9192-3.

Volkmann, M.J., \&t Anderson, M.A. (1998). Creating professional identity: Dilemmas and metaphors of a first-year chemistry teacher. Science Education,82 (3),293-310.

Yoo, J., \&t Carter, D. (2017). Teacher emotions and learning as praxis: Professional development that matters. Australian Journal of Teacher Education, 42(3), 38-52.

Zembylas, M. (2003). Emotions and teacher identity: A post structural perspective. Teachers and Teaching, 9, 213238. 